\title{
Mechanism of the AAA+ ATPases pontin and reptin in the biogenesis of H/ACA RNPs
}

\author{
ROSARIO MACHADO-PINILLA, ${ }^{1}$ DOMINIQUE LIGER, ${ }^{2}$ NICOLAS LEULLIOT, ${ }^{3}$ and U. THOMAS MEIER ${ }^{1,4}$ \\ ${ }^{1}$ Department of Anatomy and Structural Biology, Albert Einstein College of Medicine, Bronx, New York 10461, USA \\ ${ }^{2}$ Institut de Biochimie et de Biophysique Moléculaire et Cellulaire, Université de Paris-Sud, CNRS-UMR8619, IFR115, \\ 91405 Orsay Cedex, France \\ ${ }^{3}$ Laboratoire de Cristallographie et RMN Biologiques, UMR CNRS 8015, Université Paris Descartes, Sorbonne Paris Cité, Faculté des Sciences \\ Pharmaceutiques et Biologiques, 75006 Paris, France
}

\begin{abstract}
The AAA+ ATPases pontin and reptin function in a staggering array of cellular processes including chromatin remodeling, transcriptional regulation, DNA damage repair, and assembly of macromolecular complexes, such as RNA polymerase II and small nucleolar (sno) RNPs. However, the molecular mechanism for all of these AAA+ ATPase associated activities is unknown. Here we document that, during the biogenesis of H/ACA RNPs (including telomerase), the assembly factor SHQ1 holds the pseudouridine synthase NAP57/dyskerin in a viselike grip, and that pontin and reptin (as components of the R2TP complex) are required to pry NAP57 from SHQ1. Significantly, the NAP57 domain captured by SHQ1 harbors most mutations underlying X-linked dyskeratosis congenita (X-DC) implicating the interface between the two proteins as a target of this bone marrow failure syndrome. Homing in on the essential first steps of H/ACA RNP biogenesis, our findings provide the first insight into the mechanism of action of pontin and reptin in the assembly of macromolecular complexes.
\end{abstract}

Keywords: AAA+ ATPase; NAP57/dyskerin; dyskeratosis congenita; snoRNP; telomerase

\section{INTRODUCTION}

Proper function of H/ACA RNPs is important for many basic cellular processes, aberrant regulation of which can lead to cancer and underlies genetic disorders. The H/ACA, together with the C/D class of RNPs, accounts for the majority of small nucleolar (sno) RNPs functioning mainly in the site-specific modification of ribosomal and small nuclear RNAs, thus fine-tuning protein translation and premRNA splicing. Additionally, mammalian telomerase is an H/ACA RNP that adds DNA repeats to chromosome ends to protect them from telomere erosion. Each of these functions is specified by one of $>150$ noncoding H/ACA RNAs, each assembling the same four core proteins around their $3^{\prime}$ terminal H/ACA domain to form stable RNA-protein complexes. Some of these H/ACA RNAs are further processed to micro RNAs attenuating translation of target mRNAs. Significantly, mutations in the enzyme of H/ACA RNPs, the pseudouridine synthase NAP57 (also dyskerin, and Cbf5p in yeast), cause the predominant $\mathrm{X}$-linked form of the bone

\footnotetext{
${ }^{4}$ Corresponding author

E-mail tom.meier@einstein.yu.edu

Article published online ahead of print. Article and publication date are at http://www.rnajournal.org/cgi/doi/10.1261/rna.034942.112.
}

marrow failure syndrome dyskeratosis congenita (X-DC) (Meier 2005; Matera et al. 2007; Kiss et al. 2010; Mason and Bessler 2011).

Biogenesis of the five-component H/ACA RNPs is surprisingly complex involving at least two $\mathrm{H} / \mathrm{ACA}$-specific assembly factors, SHQ1 and NAF1, and several general chaperones (Kiss et al. 2010). A rate-limiting early step in RNP assembly is the interaction of NAP57 with SHQ1, which is the focus of this study (Yang et al. 2002; Grozdanov et al. 2009b). NAP57 consists of a central catalytic domain (cat) and $\mathrm{N}$ and $\mathrm{C}$ termini that wrap around each other to form the NAP $\Delta$ cat domain (Fig. 1A-C), which can be expressed independently (Grozdanov et al. 2009a). Structural information for human NAP57 encompasses only amino acids 31-422 (of 514) omitting the highly charged and unstructured $\mathrm{N}$ - and C-terminal extremities (Fig. 1, cf. B and C; only the long C-terminal extremity is shown in $\mathrm{C}$ ). The majority of the mostly missense mutations identified in patients with X-DC cluster in the NAP $\Delta$ cat domain (Meier 2006; Ye 2007; Li 2008; Hamma and Ferré-D’amaré 2010) and modulate the interaction with SHQ1 (Grozdanov et al. 2009a; Walbott et al. 2011).

SHQ1 was identified in yeast as the H/ACA-specific RNP assembly factor Shq1p (Yang et al. 2002). It consists of the N-terminal HSP90 cochaperone p23-like CS domain (90 
amino acids) and of the SHQ1-specific domain (SSD, also $\Delta \mathrm{CS}$ domain) that accounts for the majority of the protein (487 amino acids; Fig. 1D; Godin et al. 2009; Grozdanov et al. 2009b; Singh et al. 2009). Recently, we and others solved the crystal structures of the yeast orthologs of the SSD alone and in complex with the NAP $\Delta$ cat domain of NAP57, demonstrating that the SSD functions as an RNAmimic hugging the surface of NAP57 that is destined for H/ACA RNAs (Li et al. 2011; Walbott et al. 2011). Surprisingly, however, this surface in human NAP57 is distant from that harboring most X-DC mutations, leaving one wondering how they modulate the interaction of the two proteins.

Additional factors implicated in the biogenesis of H/ACA RNPs are the two closely related proteins pontin and reptin that belong to the AAA+ superfamily of ATPases (ATPases associated with diverse cellular activities) (King et al. 2001; Boulon et al. 2008; Venteicher et al. 2008; Zhao et al. 2008). Pontin and reptin have been implicated in a staggering array of basic cellular processes and carry a nearly equal number of different names, including TIP49a/b, Pontin52/ Reptin52, TIP49/48, RUVBL1/2, p55/ 50 , and NMP238 in metazoans, and Rvb1/2, Tip49/48, and Tih1/2 in yeast. The discovery of these ATPases initiated with TIP49a in rat (Kanemaki et al. 1997) and expanded to all other species (Gallant 2007; Jha and Dutta 2009; Huen et al. 2010). ATPase-associated processes include transcription, chromatin remodeling, histone acetyltransfer, DNA damage repair, mitotic spindle formation, nonsense-mediated mRNA decay, cellular transformation, and apoptosis to name a few. The role of the ATPases in assembly of macromolecular complexes such as RNA polymerase II, mRNA surveillance complexes, and notably snoRNPs appears tied to the R2TP complex that, in addition to pontin and reptin, contains RPAP3 (hSpagh) and PIH1D1 (NOP17) and that is named after the yeast homologs Rvb1, Rvb2, Tah1, and Pih1, respectively (Fig. 1E; Kakihara and Houry 2012). The involvement of pontin and reptin in these processes was predominantly identified by their presence in multi-protein complexes exhibiting the corresponding activities. Genetic depletion and siRNA-mediated mRNA knockdown studies further supported their participation, however, with- out clue as to their mode of action (Gallant 2007; Jha and Dutta 2009; Huen et al. 2010). Moreover, the role of the R2TP complex is much better documented for C/D than for H/ACA RNPs (Newman et al. 2000; Watkins et al. 2002, 2004; Boulon et al. 2008; McKeegan et al. 2009). Pontin and reptin are evolutionary highly conserved proteins with homology with bacterial helicases (Iyer et al. 2004; Ammelburg et al. 2006). The crystal structure of human pontin and that of its complex with reptin, based on negatively stained electron micrographs, are available (Matias et al. 2006; Puri et al. 2007). Apparently, the two ATPases form a heterohexa- or dodecameric ring (Fig. 1E; Cheung et al. 2010; Gorynia et al. 2011). The importance of pontin and reptin to human health is indicated by their overexpression in several cancers including hepatocellular carcinoma, colon and
A
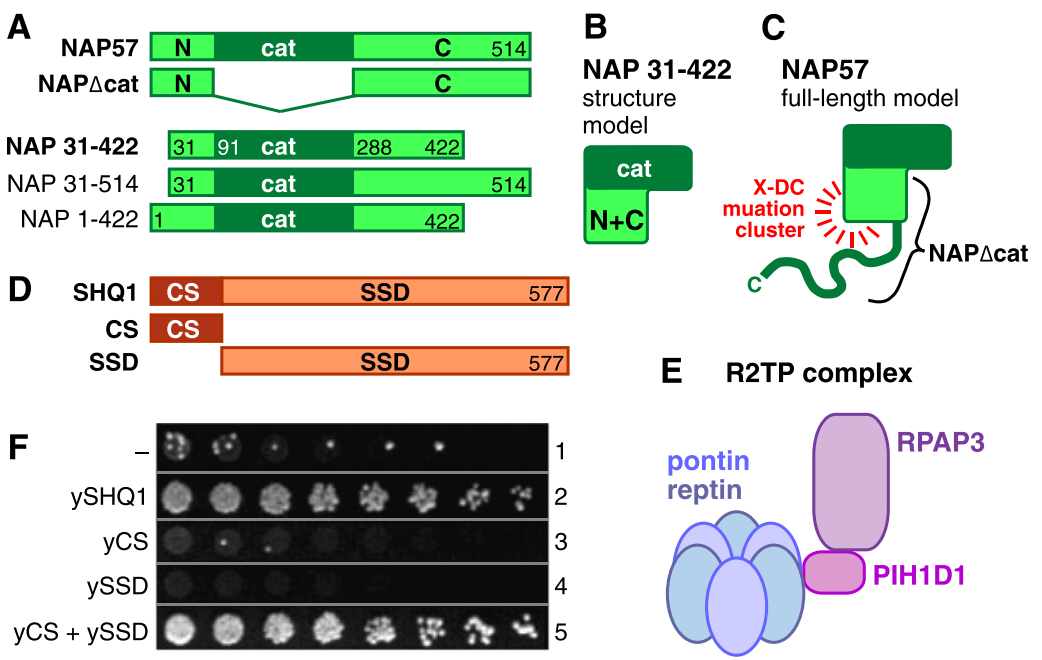

E R2TP complex
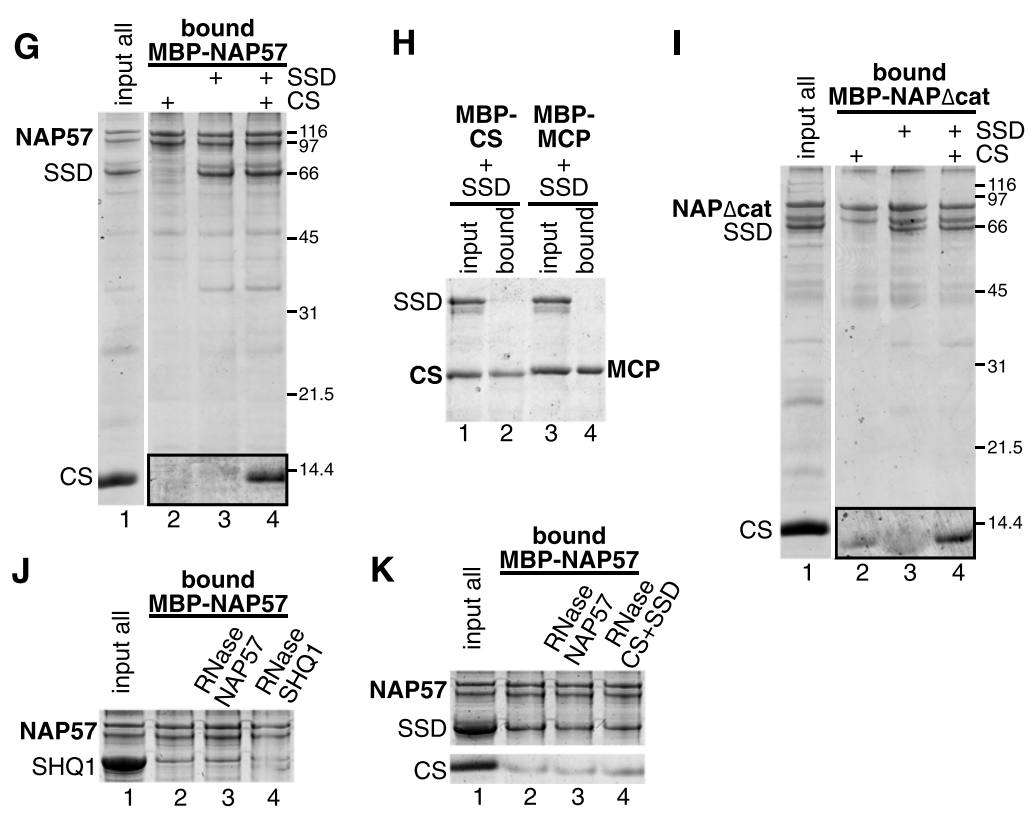

FIGURE 1. (Legend on next page)

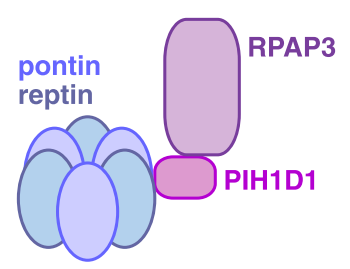

I 
bladder cancer, and melanoma (Huber et al. 2008; Jha and Dutta 2009). Despite this plethora of information on pontin and reptin over the past 15 years, no mechanistic insight has been gained on their role in any of these complexes or processes.

Here we document the interplay of the two complexes, NAP57•SHQ1 and R2TP. We show how SHQ1 clamps onto the NAP $\Delta$ cat domain of NAP57 (with the CS domain of SHQ1 on one side and the SSD on the other) forming a stable complex. Separation of this tight configuration requires the R2TP complex, which frees up NAP57 for association with an H/ACA RNA and the other H/ACA core proteins. Specifically, PIH1D1 recruits the R2TP complex to NAP57•SHQ1 allowing pontin and reptin to hold on to the C-terminal tail of NAP57 effecting SHQ1 release, apparently, in an ATP-independent fashion. Essentially, assembly of H/ACA RNPs requires disassembly.

\section{RESULTS}

\section{The CS domain of SHQ1 binds to NAP57 in trans to the SSD}

Binding of SHQ1 to NAP57 is an essential first step in H/ACA RNP biogenesis and occurs through NAP $\Delta$ cat (Grozdanov et al. 2009a,b; Li et al. 2011; Walbott et al. 2011). The SSD of SHQ1 (Fig. 1D) binds independently to NAP57, whereas the CS domain alone fails to bind (Godin et al. 2009; Grozdanov et al. 2009b), yet is essential for cell viability (Singh et al. 2009). This and other puzzles prompted us to further investigate the role of the CS domain of SHQ1 in its interaction with NAP57.
We first assessed its functionality in vivo by complementation analysis of a yeast strain depleted of the endogenous SHQ1 ortholog Shq1p. Since human SHQ1 functionally complemented that strain (Walbott et al. 2011), the yeast counterparts were used for this purpose. Although full-length Shq1p (ySHQ1) provided on a plasmid restored growth to the shq1 null strain, neither the $\mathrm{yCS}$ domain nor the ySSD of Shq1p alone were sufficient (Fig. 1F, cf. row 2 and 3,4). However, when the individual domains were provided simultaneously, they fully restored growth to the Shq1p depleted strain (Fig. 1F, row 5). Thus, the two Shq1p moieties functioned in trans to each other.

To test if this effect was due to binding of the two domains to NAP57, we used our previously developed amylose resin pull-down assay comprising recombinant human NAP57 fused to maltose binding protein (MBP) and recombinant human SHQ1 protein constructs (Grozdanov et al. 2009b). As demonstrated before, full-length SHQ1 (not shown) and its SSD bound directly to NAP57, whereas the CS domain alone failed to bind (Fig. 1G, lanes 3,2, respectively; note, in all figures, the names of the tethered/ immobilized proteins are indicated in bold and those of the potential binding partners in regular print). In contrast, the CS domain was retained by NAP57 when the SSD was present (Fig. 1G, lane 4). Although this replicated the trans effect of the two domains observed in vivo (Fig. 1F), it was unclear whether the CS domain bound to the SSD, to NAP57, or both. To investigate the first possibility, we fused the CS domain and, as control, the MS2 phage coat protein (MCP) to MBP and incubated them with the SSD. The SSD was retained by neither construct (Fig. 1H, lanes 2,4), consistent with previous data using yeast orthologs (Godin et al. 2009). This indicated that the CS domain of SHQ1, even in the presence of the SSD, required NAP57 for binding. To narrow the binding site of the CS domain of SHQ1 on NAP57, we used the NAP $\Delta$ cat construct, which like fulllength NAP57 proved sufficient for retention of the SSD but not of the CS domain alone (Fig. 1I, lanes 3,2, respectively). When provided in trans to the SSD, however, the CS domain bound to NAP $\Delta$ cat (Fig. 1I, lane 4). Because NAP57 is an RNA binding protein and although RNA and SHQ1 binding are mutually exclusive ( $\mathrm{Li}$ et al. 2011; Walbott et al. 2011), we ascertained that the protein-protein interactions were direct and not mediated by bacterial RNA that might have copurified. Indeed, RNase treatment of either protein had no effect on NAP57 binding of fulllength SHQ1 or of its CS domain and SSD in trans (Fig. 1J,K, respectively). We 
conclude that direct interaction of the SSD of SHQ1 with NAP $\Delta$ cat stabilized or induced a ternary complex with the CS domain.

\section{SHQ1 clamps onto the DC mutation cluster of NAP57}

Having demonstrated that the SSD is an RNA-mimic docking to the RNA binding surface of NAP $\Delta$ cat (Li et al. 2011; Walbott et al. 2011), we probed if the CS domain of SHQ1 might bind on the opposite side where most X-DC mutations cluster. The pathogenic mutations of methionine 350 of NAP57 to isoleucine and threonine enhance and reduce, respectively, its affinity for full-length SHQ1 (Grozdanov et al. 2009a). When the binding of the CS domain of SHQ1 in trans to its SSD was compared with that of wild-type NAP57 (Fig. 2A, lane 5), the reducing NAP57 mutation (M350T) abolished binding (lane 6) and the enhancing mutation (M350I) had little effect (lane 5). Therefore, the impact of the X-DC mutation in NAP57 that reduced binding to SHQ1 (Grozdanov et al. 2009a) was amplified in trans abolishing binding of the CS domain of SHQ1 altogether. Binding of the SSD alone was unaffected by the disease mutations on the opposite side of NAP57 (Fig. 2B). These data indicated that the CS domain of SHQ1 bound to the surface with the major X-DC mutation cluster, opposite from the RNA binding surface of NAP $\Delta$ cat where the SSD bound. In this manner, the CS domain of SHQ1 and its SSD sandwiched NAP $\Delta$ cat between them (see model in Fig. 7C, below).

Such an interlocking configuration should result in a stable complex between NAP57 and SHQ1. Indeed, despite the salt-sensitivity of association of SHQ1 and NAP57 (Fig. 2C, lanes 2-5; Grozdanov et al. 2009a), once formed, their complex withstood salt concentrations of even $2 \mathrm{M}$ sodium chloride (lanes 6-9). Moreover, high salt was unable to remove the individual SHQ1 domains, CS and SSD, from NAP57 when bound in trans (Fig. 2D, lanes 6-9) and the NAP $\Delta$ cat domain was sufficient for this tight interaction (Fig. 2E, lanes 6-9). In summary, SHQ1 could not be removed from NAP57 once bound, indicating a very low off rate and illustrating its viselike grip on NAP57.

\section{ATP-independent release of SHQ1 by cytosolic factors}

The tight binding of SHQ1 to NAP57 suggested that their separation required chaperones. Several chaperones have been implicated in snoRNP biogenesis, in particular, the $\mathrm{AAA}+\mathrm{ATPases}$ pontin and reptin, the R2TP complex that additionally includes PIH1D1 and RPAP3 (Fig. 1E), HSP90, and several others (Newman et al. 2000; King et al. 2001; Watkins et al. 2002, 2004; McKeegan et al. 2007, 2009; Venteicher et al. 2008; Zhao et al. 2008; Boulon et al. 2010). As AAA+ proteins are known for breaking protein-protein interactions, e.g., the prototypical AAA protein N-ethylmaleimide-sensitive factor (NSF) disassembles SNAP-SNARE complexes (Zhao et al. 2012), we tested if pontin and reptin functioned similarly in the separation of NAP57 and SHQ1.

Purified recombinant pontin and reptin were added to the preformed complex of SHQ1 and MBP-NAP57 in the presence and absence of ATP. Compared with the untreated complex (Fig. 3A, lane 2), none of these additions released SHQ1 from NAP57 (lanes $3-8)$, suggesting that the recombinant proteins were insufficient or inactive. To account for these possibilities, we incubated the NAP57•SHQ1 complex with HeLa cytosolic S100 extract that, except for snoRNAs, contained all factors required for assembly of functional H/ACA RNPs including pontin (shown 


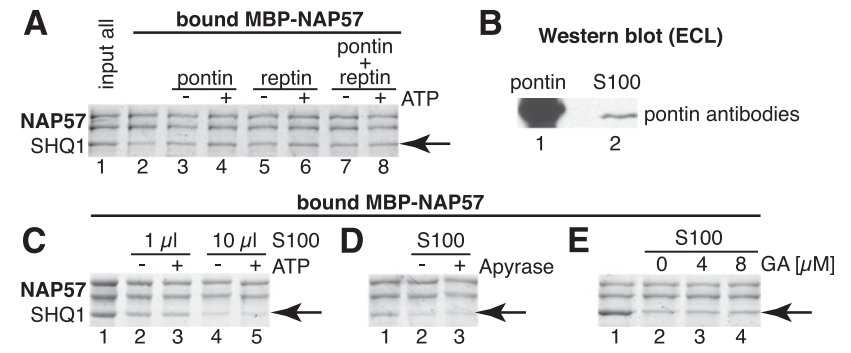

FIGURE 3. SHQ1 can be released from NAP57 by cytosolic $S 100$ extracts in an ATP- and HSP90-independent fashion. (A,C-E) Amylose resin pull-down assays as in Figure 1G-K. (A) SHQ1 bound to MBP-NAP57 (lane 2) was incubated with recombinant pontin, reptin, or both $(2.5 \mu \mathrm{g}$ each) in the presence $(+)$ and absence $(-)$ of 1 mM ATP. (B) Western blot of recombinant pontin (lane 1) and cytosolic S100 extract (lane 2) probed with pontin antibodies and developed with enhanced chemiluminescence (ECL). (C) SHQ1 bound to MBP-NAP57 (lane 1) was incubated with $1 \mu \mathrm{L}$ and $10 \mu \mathrm{L}$ of $\mathrm{S} 100$ extract in the presence $(+)$ and absence $(-)$ of $1 \mathrm{mM}$ ATP. $(D)$ SHQ1 bound to MBP-NAP57 was incubated with S100 that was pretreated with $(+)$ and without $(-)$ Apyrase $(140 \mathrm{mU} / \mu \mathrm{L})$ for 30 min at $37^{\circ} \mathrm{C}$. (E) SHQ1 bound to MBP-NAP57 was incubated with S100 that was pretreated with the HSP90 inhibitor geldanamycin (GA) at 0,4 , and $8 \mu \mathrm{M}$ for $60 \mathrm{~min}$ at $37^{\circ} \mathrm{C}$.

by immunoblot in Fig. 3B; Wang and Meier 2004). S100 extract removed SHQ1 from MBP-NAP57 in a concentration-dependent manner (Fig. 3C, cf. lanes 1,2, and 4). Surprisingly, addition of ATP to the extensively dialyzed extract had no impact on the release reaction (Fig. 3C, lanes 3,5). In fact, further depletion of ATP from the extract by preincubation with apyrase similarly failed to affect the release activity in the extract (Fig. 3D). Although the apparent ATP independence of the release reaction seemed to preclude the involvement of HSP90, we further probed for HSP90 contribution by incubation of the S100 extract with a more specific HSP90 inhibitor, geldanamycin (Stebbins et al. 1997). However, at 4 and $8 \mu \mathrm{M}$, geldanamycin failed to impact the release activity of S100 extract (Fig. 3E). Therefore, release of SHQ1 from MBP-NAP57 apparently occurred independent of ATP and HSP90. The latter is consistent with the failure of HSP90 to interact with the CS domain of SHQ1, which is homologous with the HSP90 cochaperone p23 (Godin et al. 2009; Singh et al. 2009).

\section{Pontin and reptin are required for SHQ1 release}

To investigate if pontin formed part of the release activity in S100 extract, the impact of pontin antibodies was tested. Pontin antibodies inhibited S100-mediated release of SHQ1 from NAP57 (Fig. 4A, top panel, cf. lanes 2 and 3). Moreover, after SHQ1 release, pontin from the extract remained bound to NAP57 (Fig. 4A, bottom panel, lane 2) but not to the control protein MCP (lane 4), nor when quenched by antibodies (lanes 3,5). To ascertain that the inhibition of SHQ1 release by the pontin antiserum was due to antibodies directed against pontin (and not a nonspecific factor in the serum), increasing amounts of recombinant pontin were added to the antiserum. In this experiment, pontin (Fig. 4B, lanes 4-6), but not reptin (lanes 7-9), reversed the inhibition of SHQ1 release by pontin antiserum (lane 3) in a concentration-dependent manner. Similarly, reptin antiserum inhibited S100-mediated SHQ1 release (Fig. 4C, cf. lanes 2 and 3), which was quenched in a concentrationdependent manner by recombinant reptin (lanes 4-6) but not pontin (lanes 7-9). Therefore, pontin and reptin were required for SHQ1 release.

Given that the individual SHQ1 domains, CS and SSD, also bound tightly to MBP-NAP57 when provided in trans (Fig. 2D), we tested if S100 could release them, together or individually, and if this was pontin and reptin mediated. As
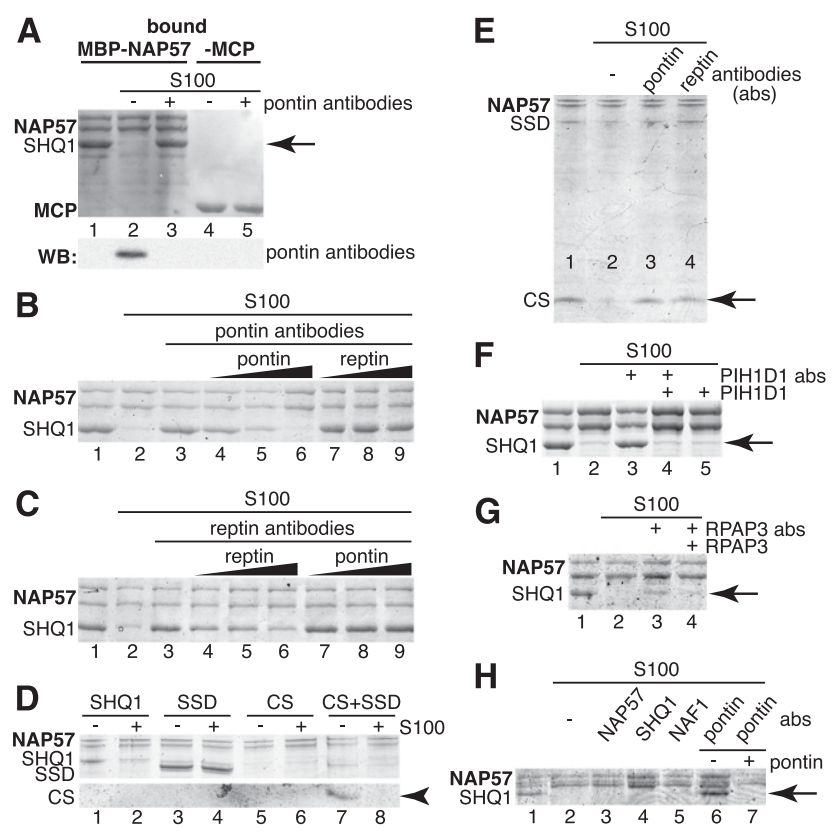

FIGURE 4. Acting on the CS domain of SHQ1, all components of the R2TP complex are required for SHQ1 removal from NAP57. (A) SHQ1 bound to MBP-NAP57 (lanes 1-3) or to control MBP-MCP (lanes 4,5 ) in amylose resin pull-down assays as in Figure 3C-E, except that the SDS-PAGE was transferred to nitrocellulose and stained with amido black (upper panel) and probed with pontin antibodies (lower panel). The bound proteins were incubated with S100 that was pretreated with $(+)$ and without $(-)$ pontin antibodies. $(B-H)$ Same as $A$ but coomassie blue stained gels. (B) SHQ1 bound to MBP-NAP57 (lane 1) was released with S100 extract (lane 2), which was pretreated with pontin antibodies (lane 3 ) that were incubated with $0.5,1.5$, and $2.5 \mu \mathrm{g}$ of recombinant pontin (lanes 4-6) or reptin (lanes 7-9). (C) Same as B but with reptin antibodies. (D) MBPNAP57 was incubated with the SHQ1 constructs indicated above the gel and treated with (+) and without (-) S100. Note the SSD bound to MBP-NAP57 was not removed by S100 (lanes 3,4). (E) The CS domain of SHQ1 bound in trans to its SSD to MBP-NAP57 was removed by $\mathrm{S} 100$ (lane 2), which was inhibited by pontin and reptin antibodies (lanes 3,4). (F) PIH1D1 antibodies inhibited S100-mediated removal of SHQ1 from MBP-NAP57 (lane 3). The inhibition was relieved by recombinant PIH1D1 (lane 4). (G) Same as $F$ but with RPAP3 antibodies and protein. $(H)$ Control. Unlike pontin antibodies (lane 6), antibodies directed against NAP57, SHQ1, and NAF1 did not inhibit the release activity of S100 extracts (lanes 3-5, respectively). 
observed above, S100 released full-length SHQ1 from MBP-NAP57 (Fig. 4D, lanes 1,2) whereas binding of the SSD was unaffected by incubation with S100 (lanes 3,4) and the CS domain alone was unable to bind (lanes 5,6), as observed previously (Fig. 1G; Godin et al. 2009; Grozdanov et al. 2009b). However, when bound in trans, S100 quantitatively removed the CS domain of SHQ1 but barely impacted binding of its SSD (Fig. 4D, cf. lanes 7 and 8). Moreover, removal of the CS domain (bound in trans to the SSD) required pontin and reptin because antibodies to these proteins inhibited its release by S100 (Fig. 4E, cf. lane 2 and 3,4). These data suggested that pontin and reptin primarily acted on the N-terminal CS domain of SHQ1 when removing full-length SHQ1 from NAP57.

\section{The R2TP complex is required for SHQ1 release}

We investigated the involvement in SHQ1 release of the two other components of the R2TP complex, PIH1D1 and RPAP3, because recombinant pontin and reptin were insufficient for SHQ1 removal (Fig. 3A). PIH1D1 antiserum inhibited the SHQ1 release activity of S100 extract (Fig. 4F, lane 3) and the inhibition could be relieved by addition of recombinant PIH1D1 (lane 4), which on its own did not affect the release reaction (lane 5). Similarly, RPAP3 monoclonal antibodies inhibited the release reaction (Fig. 4G, lane 3), which could be rescued by recombinant RPAP3 (lane 4). Importantly, antibodies to NAP57, SHQ1, or the other H/ACA-specific assembly factor NAF1 had no impact on the release activity in S100 extracts documenting the specificity of inhibition by antibodies to the components of the R2TP complex (Fig. 4H). Therefore, all components of the R2TP complex were required for removal of SHQ1 from NAP57.

\section{The R2TP complex interacts directly with NAP57 and SHQ1}

To gain mechanistic insight into the function of the R2TP complex in SHQ1 removal from NAP57, we probed the physical interactions of all components using recombinant proteins. Specifically, the interactions of pontin and reptin with NAP57 (Fig. 5A-D) and SHQ1 constructs (Fig. 5E-G), of PIH1D1 with NAP57 (Fig. 5H), of RPAP3 with NAP57 (Fig. 5I), and of PIH1D1 and RPAP3 with SHQ1 (Fig. 5J) were tested. For schematics of the constructs, see above (Fig. 1A-E).

Although an association between pontin and NAP57 has been reported (Venteicher et al. 2008) and noted in the S100 extract (Fig. 4A), we investigated if that was also the case for reptin, if the interaction occurred directly, and where (Fig. 5A-D). Specifically, we incubated recombinant pontin and reptin alone or together with MBP-NAP57 or, as control, with MBP-MCP and determined if the fusion proteins retained them when immobilized on amylose resin via their MBP moiety. Both pontin and reptin alone and together bound directly to NAP57 (Fig. 5A, lanes 7-9) but not to the MCP control protein (lanes 10-12). Note a larger read-through product copurifies with recombinant reptin (e.g., Fig. 5A, lane 2) that also binds to NAP57 (lane 8). This higher band migrates closely to pontin and on most occasions is not separated from it (e.g., Fig 5B, lane 10). In binding studies to individual domains of NAP57, we mapped the binding of pontin and reptin to the NAP $\Delta$ cat domain (Fig. 5B, lane 9), the same domain that SHQ1 clamps onto. Interestingly, the C terminus of NAP57 (NAP-C) alone was insufficient for pontin and reptin binding (Fig. $5 \mathrm{~B}$, lane 8); binding depended on the presence of the $\mathrm{N}$ terminus (lane 9), which as part of the NAP $\Delta$ cat domain contributes to the X-DC mutation cluster that is contacted by the CS domain of SHQ1 (Fig. 2A). Pontin and reptin also bound individually to NAP $\Delta$ cat (Fig. 5C, lanes 3,4). To further narrow down the interaction domain on NAP57, we removed its highly charged and unstructured $\mathrm{N}$ - and C-terminal extremities yielding NAP 31-422 (see Fig. 1A,B). Pontin and reptin alone and together bound to this construct (Fig. 5D, lanes 4-6), as did SHQ1 (Walbott et al. 2011), narrowing down their interaction domain on NAP57 to amino acids 31-90 and 288-422 ( $+\mathrm{C}$ domain in Fig. 1B). Therefore, pontin and reptin bind to the same domain on NAP57, NAP $\Delta$ cat, as SHQ1 without the help of the highly charged and unstructured terminal extremities. Whether binding occurs simultaneously or sequentially remains to be determined.

We investigated if pontin and reptin interacted with SHQ1 (Fig. 5E-G). Individually and together, pontin and reptin were retained by MBP-SHQ1 (Fig. 5E, lanes 4-6). When they were added to the CS domain of SHQ1 (fused to MBP), they both bound to that domain (Fig. 5F, lanes 4-6). In reverse experiments, wherein pontin and reptin were tethered (to glutathione beads via GST moieties), only the CS domain but not the SSD was retained (Fig. 5G, lanes 4,3 , respectively), even when provided simultaneously (lane 6). This confirmed the result with the MBP-CS construct (Fig. 5F) and was consistent with the earlier observation that the pontin- and reptin-dependent removal of SHQ1 from NAP57 required the presence of the CS domain of SHQ1 (Fig. 4D,E).

The other two components of the R2TP complex, PIH1D1 and RPAP3, were also tested for their interaction pattern with NAP57 and SHQ1 (Fig. 5H-J). PIH1D1 bound to full-length NAP57 and to NAP $\Delta$ cat but not to its catalytic domain alone or to the MCP control protein (Fig. 5H, lanes 5-8). RPAP3 failed binding to even fulllength NAP57, alone (Fig. 5I, lane 3) and in the context of the other proteins of the R2TP complex (R2P, lane 4). Neither PIH1D1 nor RPAP3 interacted with SHQ1 (Fig. 5J, lanes 3,4). In summary, pontin and reptin associated with both NAP57 and SHQ1, whereas PIH1D1 only bound NAP57, and RPAP3 interacted with neither protein. These 

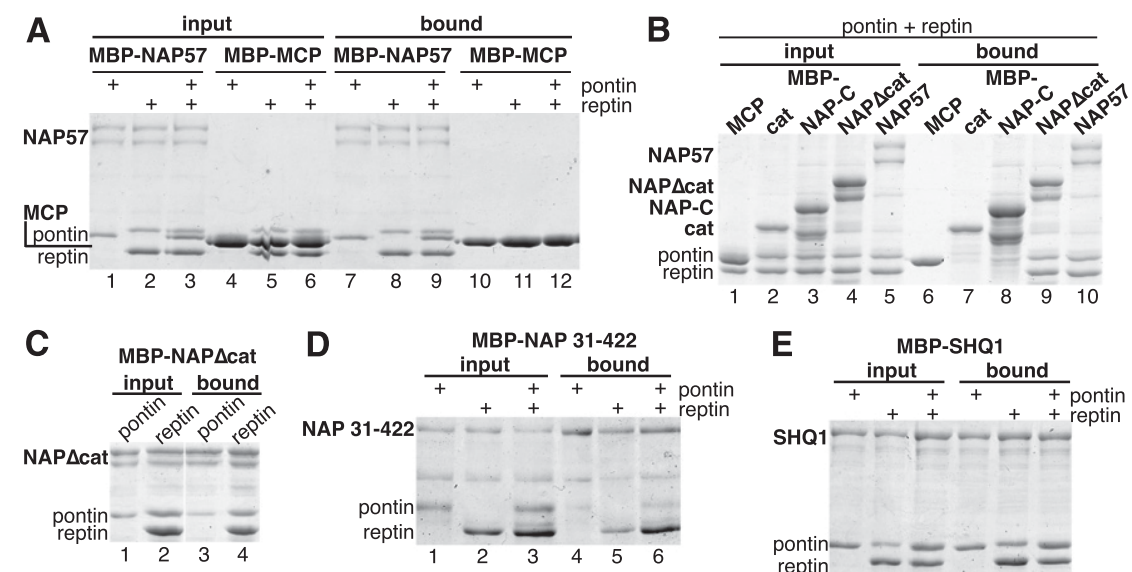

D

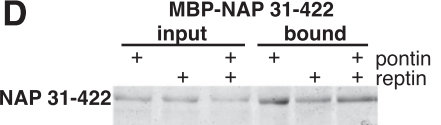

E
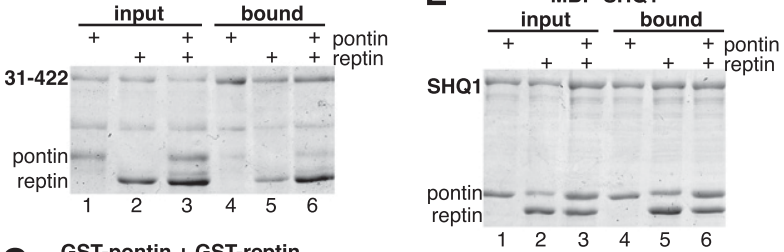

G GST-pontin + GST-reptin input bound $\frac{\text { in }}{+} \frac{\text { b. }}{+}$
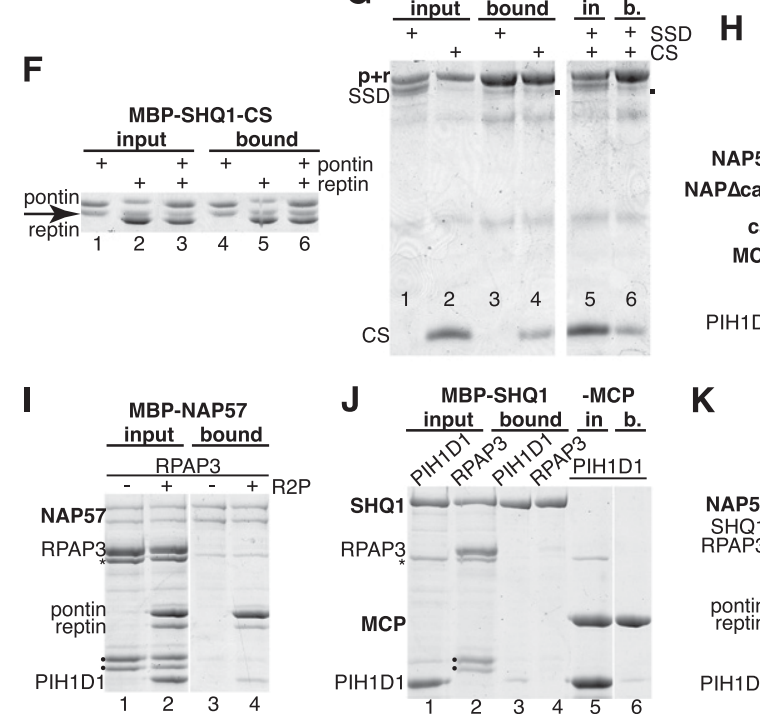

\section{CS 西}
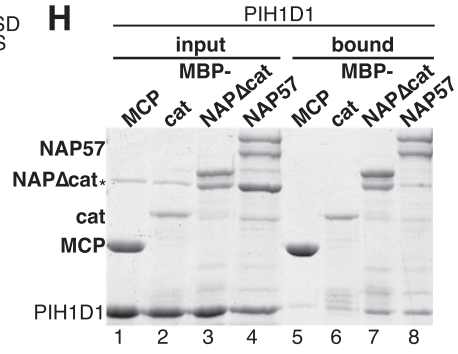

$\mathrm{K}$

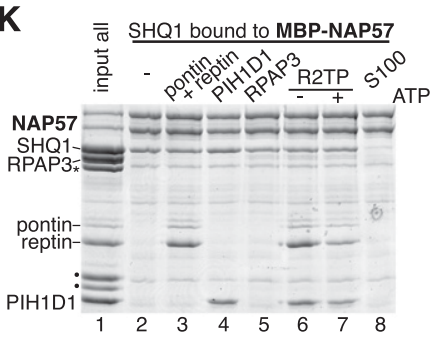

FIGURE 5. Mapping of direct interactions of NAP57 and SHQ1 with the components of the R2TP complex. All panels, except $G$ (which is a glutathione bead pull-down), are amylose resin pull-downs as in Figure $1 \mathrm{G}-\mathrm{K}$. $(A)$ Incubation of pontin and reptin alone and together with MBP-NAP57 and control MBP-MCP. Note recombinant reptin (lane 2) includes a minor band that migrates closely to pontin and is apparently a read-through product because it also binds to NAP57 (lane 8). (B) Incubation of pontin and reptin combined with MBP-NAP57 constructs identifies the NAP $\Delta$ cat domain as docking site (lane 9). (C) Pontin and reptin bind also individually to NAP $\Delta$ cat. $(D)$ Pontin and reptin, alone and together, bind to NAP57 without its charged and unstructured terminal extremities, MBP-NAP 31-422. (E) Pontin and reptin alone and together bind to MBP-SHQ1. (F) Pontin and reptin alone and together bind to the CS domain of SHQ1. Note MBP-CS migrates between pontin and reptin (arrow). $(G)$ Glutathione-S-transferase (GST) fusions of pontin and reptin combined incubated with the CS domain of SHQ1 and its SSD individually (lanes 1-4) and together (lanes 5,6). A minor band from the fusion proteins that migrates right below the SSD is marked (black square). $(H)$ Incubation of PIH1D1 with MBP-NAP57 constructs identifies NAP $\Delta$ cat as the binding domain (lane 7). (I) RPAP3 fails to bind to MBP-NAP57 alone (lane 2) and in the context of the other three R2TP components (R2P), which are retained (lane 4). Note a bacterial heat shock protein that sometimes copurifies with MBP-NAP57 and PIH1D1 migrates below RPAP3 (asterisk), and two lower bands contaminate the RPAP3 preparations (black dots). ( $J$ ) Neither PIH1D1 (lane 3) nor RPAP3 (lane 4) bind to MBP-SHQ1. Note equal background level binding of PIH1D1 to control MBP-MCP (lane 6). (K) Unlike S100 (lane 8), neither pontin and reptin combined, PIH1D1, RPAP3, nor altogether (R2TP) release SHQ1 from MBP-NAP57, irrespective of $1 \mathrm{mM}$ ATP addition. However, pontin, reptin, and PIH1D1, when present, are retained by the complex (lanes 3,4,6,7).

data support a model in which the R2TP complex is recruited to the NAP57•SHQ1 complex by PIH1D1 to the NAP $\Delta$ cat domain of NAP57 and pontin॰reptin additionally to the CS domain of SHQ1.

Finally, we tested if the entire recombinant R2TP complex was sufficient for SHQ1 release (Fig. 5K). When added to the preformed NAP57•SHQ1 complex, neither the R2TP components individually nor in complex succeeded in SHQ1 release (Fig. 5K, lanes 3-6), independent of ATP addition (lane 7), but in contrast to S100 extract (lane 8). Nevertheless and consistent with the binding data above, pontin, reptin, and PIH1D1, but not RPAP3, were retained on the complex. These data suggested that additional factors in the S100 extract were required for the release reaction or that the recombinant R2TP complex was inactive.

\section{Pontin and reptin are required for H/ACA RNP accumulation in vivo}

To determine if pontin and reptin (and the R2TP complex) also functioned in the cell in H/ACA RNP biogenesis, we studied the effect of their siRNA-mediated knockdown (Fig. 6). As anticipated from previous studies, knockdown of both pontin and reptin caused a depletion of pontin due to their coexistence in a heterohexameric ring (Fig. 6A, lanes 3,4). Knockdown of pontin and reptin also resulted in a loss of NAP57 and NHP2 (Fig. 6A), indicating an overall destabilization of H/ACA RNPs. However, SHQ1, Nopp140 (another protein implicated in snoRNP biology), and tubulin levels remained unaffected indicating that SHQ1 by itself was stable. Given that pontin and reptin are also implicated in C/D RNP biogenesis (Newman et al. 2000; King et al. 2001), it was not surprising that their knockdown also diminished the $\mathrm{C} / \mathrm{D}$ core protein fibrillarin (Fig. 6A). Additionally, fibrillarin, but none of the other proteins, was lost when control siRNA against fibrillarin was employed (Fig. 6A, lane 2). Furthermore, pontin and reptin knockdown caused a reduction in the H/ACA RNAs, E3, U17/E1, and human telomerase RNA 

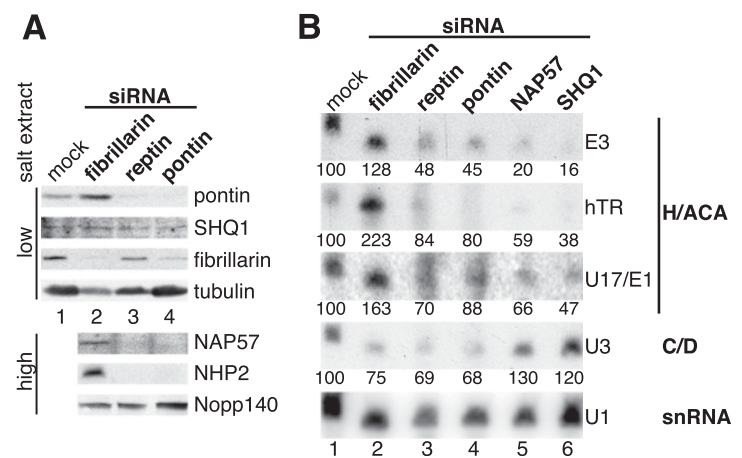

FIGURE 6. Pontin and reptin are required for H/ACA RNP accumulation in vivo. $(A)$ Western blots of low and high salt cell extracts from HeLa cells treated with the siRNAs to the targets indicated on top (in bold) and probed with antibodies to the proteins indicated on the right. Pontin and reptin knockdowns deplete pontin, fibrillarin, NAP57, and NHP2, but not SHQ1 nor tubulin or Nopp140 (lanes 3,4 ), whereas fibrillarin knockdown only depletes fibrillarin (lane 2). (B) Northern blots of total RNA extracted from cells treated with siRNAs to the targets indicated on top (in bold) and probed for RNAs indicated on the right. The amounts of the snoRNAs are each expressed as percent relative to the mock treated sample and were quantified relative to snRNA U1.

hTR, and in the C/D RNA U3 (Fig. 6B, lanes 3,4), whereas knockdown of NAP57 and SHQ1 only reduced the levels of the H/ACA RNAs (lanes 5,6). Knockdown of fibrillarin caused a decrease in U3 but a slight increase in H/ACA RNAs (Fig. 6B, lane 2), as observed previously (Grozdanov et al. 2009b). In summary, knockdown of pontin and reptin caused an overall reduction in snoRNPs, both $\mathrm{H} / \mathrm{ACA}$ and $\mathrm{C} / \mathrm{D}$, including their core proteins, whereas knockdown of NAP57 and SHQ1 specifically impeded H/ACA RNP accumulation.

\section{The R2TP complex catches NAP57 by its tail}

How does the R2TP complex effect the release of SHQ1 from NAP57? We already determined that the CS domain of SHQ1 (to which pontin and reptin bind) and the NAP $\Delta$ cat domain of NAP57 (which is the target of both PIH1D1 and pontin and reptin) are required for the separation of the two proteins. AAA+ ATPases usually form hexameric rings through which they thread strands of molecules they interact with, i.e., DNA in case of helicases and polypeptide chains in case of unfoldases (Ogura and Wilkinson 2001). Given that the highly charged, 30-amino acid-long $\mathrm{N}$ - and 92-amino acid-long C-terminal tails of NAP57 show low complexity and appear unstructured, we asked if they were required for R2TP-mediated release of SHQ1 from NAP57. When SHQ1 was added to full-length NAP57 (Fig. 7A, 1-514, lane 1) and to NAP57 without its terminal extremities (31-422, lane 2), they both bound (lanes 3,4, respectively), as observed previously (Walbott et al. 2011). However, S100 extract released SHQ1 only from full-length NAP57 (Fig. 7A, lane 5) but not from that lacking its ends (lane 6). To determine which of the termini or if both were required, we investigated SHQ1 release from NAP57 missing only the N-terminal (NAP 31-514) or the C-terminal (NAP 1-422) extremity (Fig. 7B; see Fig. 1A for constructs). Whereas all constructs bound SHQ1 (Fig. 7B, lanes 1-4), S100 released SHQ1 only from full-length NAP57 (1-514, lane 5) and from that missing its N-terminal extremity (31-514, lane 6). In contrast, both constructs missing the C-terminal tail of NAP57 alone (Fig. 7B, 1-422, lane 7) or in combination with the $\mathrm{N}$-terminal piece (31422 , lane 8) proved resistant to S100-mediated SHQ1 release. Therefore, the unstructured C-terminal tail of NAP57 was essential for R2TP-mediated release.

\section{DISCUSSION}

Fifteen years since the discovery of the AAA+ ATPases pontin and reptin and an ever-expanding array of basic cellular processes they are associated with, we provide the first insight into their mode of action. Specifically, our data imply the following model of NAP57 and SHQ1 association and dissociation, which are essential first steps in the biogenesis of all H/ACA RNPs including telomerase. SHQ1 binds to the NAP $\Delta$ cat domain of NAP57 on two sides, with the SSD on the RNA binding surface and with the CS domain on the surface that exposes the major X-DC mutation cluster (Fig. 7C). Thus, SHQ1 binds viselike to NAP57 requiring chaperones for its release. The R2TP complex, comprising the AAA+ ATPases pontin and reptin in a heterohexameric ring and PIH1D1 and RPAP3, is recruited to the NAP57•SHQ1 complex by PIH1D1, which attaches to NAP $\Delta$ cat, and by pontin and reptin, which bind to the CS domain of SHQ1 (Fig. 7C, a). This positions the C-terminal tail of NAP57 so that it can be engaged by the AAA+ ATPase ring to unlock SHQ1 from NAP57 (Fig. 7C, a). Additionally or alternatively, the ATPase ring, which can interact with both the CS domain of SHQ1 and the NAP $\Delta$ cat domain of NAP57, undergoes a conformational change physically separating the two proteins (Fig. 7C, b). In either case, this allows access to an H/ACA RNA and the other core proteins, eventually resulting in a mature $\mathrm{H}$ / ACA RNP.

Several key experiments support this model. The high affinity of SHQ1 for NAP57 is supported by the fact that the CS domain of SHQ1 binds to NAP57 only in trans to the SSD and on the opposing side of NAP57 (Figs. 1G-K; $2 \mathrm{~A}$ ), and that it cannot be released by high salt concentration. The requirement for the SSD to allow binding of the CS domain to NAP57 indicates that the SSD interaction with NAP57 induces an allosteric rearrangement in NAP57 (and SSD) and/or provides an additional surface stabilizing the trimer consisting of the CS domain, the SSD, and NAP57. Docking of the CS domain of SHQ1 onto the surface of NAP57 that harbors the major X-DC mutation cluster, in addition to the interaction of the SSD with 


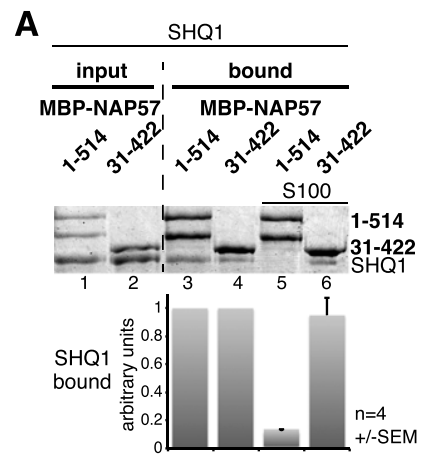

C
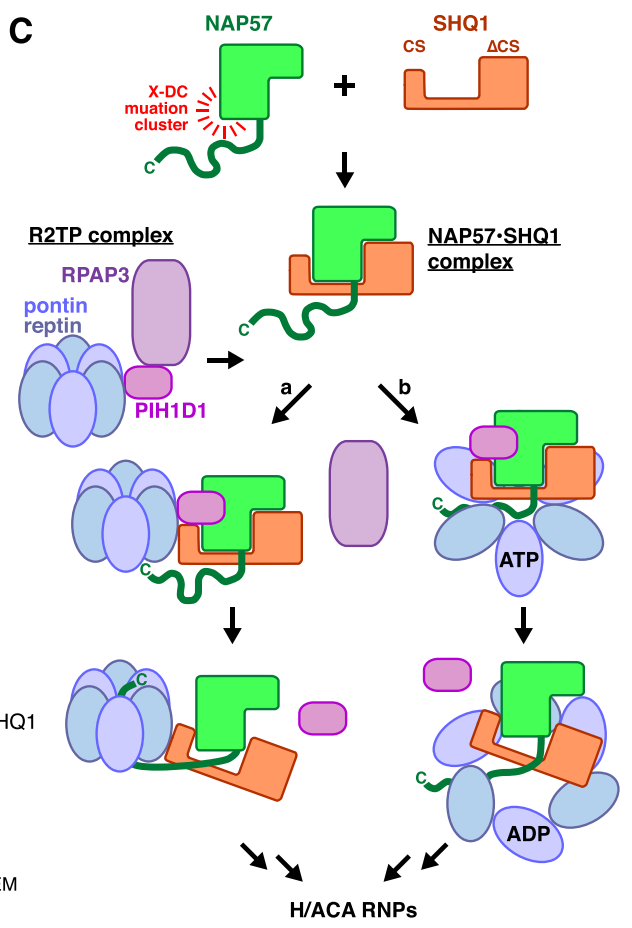

FIGURE 7. Mode of action of the R2TP complex on the NAP57•SHQ1 complex. $(A)$ The NAP57 extremities are required for S100-mediated release from SHQ1. SHQ1 bound to fulllength (1-514, lane 3$)$ or to NAP57 without its extremities (31-422, lane 4) was only released by S100 from the former (lane 5) but not the latter (lane 6). Histogram of the quantification of SHQ1 release relative to bound protein (below). (B) The C-terminal tail of NAP57 alone is required for S100-mediated SHQ1 release. SHQ1 bound to full-length NAP57 (1-514, lane 1), to NAP57 without N-terminal extremity (31-514, lane 2), without C-terminal tail (1-422, lane 3), and without both extremities (31-422, lane 4). S100 only released SHQ1 from NAP57 constructs with the C-terminal tail (lanes 5,6) but not from those without it (lanes 7,8). Note MBP-NAP57 lacking its C-terminal tail migrates as a single band (e.g., lanes 7,8). (C) Schematic summary of the results. See text for details.

a domain containing other mutations observed in X-DC (Walbott et al. 2011), explains why the interaction of SHQ1 with NAP57 is modulated by X-DC mutations (Grozdanov et al. 2009a). Therefore, small molecules that target the interaction of SHQ1 with NAP57 could form a basis for therapeutic intervention in X-DC.

The R2TP complex and its components have been implicated in snoRNP biogenesis overall and that of telomerase specifically (Newman et al. 2000; King et al. 2001; Watkins et al. 2002, 2004; McKeegan et al. 2007, 2009; Boulon et al. 2008; Venteicher et al. 2008; Zhao et al. 2008). Here we define the actual step in H/ACA RNP assembly in which the R2TP complex functions: It is required for SHQ1 release from NAP57 in vitro and in vivo, i.e., antibodies to its components specifically inhibit SHQ1 release and knockdown of pontin and reptin causes a loss of H/ACA RNPs. SHQ1 removal depends on its CS domain, to which pontin and reptin bind (Fig. 5F,G), because the SSD alone is not subject to removal by the ATPases (Fig. 4D,E). Additionally, PIH1D1 is required for the release (Fig. 4F) and binds to the NAP $\Delta$ cat domain of NAP57 (Fig. $5 \mathrm{H}$ ), recruiting pontin and reptin or assisting in the release reaction. The recruitment of the $\mathrm{R} 2 \mathrm{TP}$ complex through PIH1D1 could be similar to that of the scaffold protein TEL2 (Horejsí et al. 2010), although phosphorylation of SHQ1 is apparently not required for its interaction with PIH1D1 because it occurs between bacterially expressed proteins (Fig. $5 \mathrm{H}$ ). The involvement of RPAP3 is less clear, as it fails to interact with any of the participants (Fig. 5I-K). The role of RPAP3 could be indirect, possibly through stabilization of PIH1D1, as reported (Zhao et al. 2008), but apparently without the help of HSP90 (Grozdanov et al. 2009b). Therefore, the main actors in SHQ1 release are pontin, reptin, and PIH1D1 (i.e., the R2P complex), which is consistent with previous observations that RPAP3 (and HSP90) was only important under stress conditions, such as stationary phase in yeast (Huen et al. 2010), and that an R2Ponly complex could be separated from larger complexes containing the ATPases on sucrose gradients of yeast extracts (Pih1 = YHR034c; Jónsson et al. 2004). Finally, even more factors may be required for this seemingly simple separation of two proteins because recombinant R2TP alone was insufficient (Fig. $5 \mathrm{~K})$. Potential candidates include the prefoldin proteins that have been shown to cooperate with the function of the R2TP complex in the assembly of RNA polymerase II and PIKKs, or the PIH1D1interacting TEL2 itself (Boulon et al. 2010; Horejsí et al. 2010).

AAA+ ATPases are known to form hexameric rings and apparently function in one of two major ATP-dependent fashions, the threading of their target molecules through the central orifice and the application of rotary force along the ring. The former is dramatically illustrated by the forces generated by the bacterial unfoldase ClpX while engaging a polypeptide chain (Maillard et al. 2011) and the latter by SNARE disassembly (Ogura and Wilkinson 2001). In our case of pontin and reptin in H/ACA RNP biogenesis, either model is conceivable (Fig. 7C, a and b). We prefer model a, proposing that the ATPases thread the C-terminal tail of NAP57 through their central orifice to separate NAP57 from SHQ1 (Fig. 7C, a), because the tail of NAP57 is required for release (Fig. 7B) and because it is unstructured. In fact, the tail of NAP57 may promote two SDS-resistant conformations of NAP57 because in its absence NAP57 migrates as a single band on SDS-PAGE (e.g., Fig. 5B, lane 7; Fig. 7B, lanes 7,8), whereas all NAP57 constructs that 
include the tail migrate as a doublet (Grozdanov et al. 2009a,b; Walbott et al. 2011). Therefore, the tail could promote a "threading-ready" conformation in NAP57. Such a tail-dependent mechanism could be analogous to that of the red algae AAA+ protein CbbX, which activates Rubisco by pulling on its C-terminal tail (Mueller-Cajar et al. 2011). Nevertheless, binding of pontin and reptin to both target proteins, SHQ1 (through its CS domain) and NAP57 (through its NAP $\Delta$ cat domain) (Fig. 5A-F), offers potential handles for the ring to pry apart the two proteins, simply by changing the conformation of their ring (Fig. 7C, b). However, this model fails to explain why the unstructured tail of NAP57 is not required for pontin and reptin binding (Fig. 5D) yet is essential for the separation of NAP57 and SHQ1. Of course, the two models are not mutually exclusive and could function concordantly.

Targeting of the highly charged and unstructured tail of NAP57 by the AAA+ ATPases is an attractive mechanism not only for the biogenesis of H/ACA RNPs but also that of C/D RNPs because the R2TP complex is required for their assembly (Newman et al. 2000; Watkins et al. 2002, 2004; Boulon et al. 2008; McKeegan et al. 2009) and because the C/D core proteins NOP56 and NOP58 end in homologous tails (Gautier et al. 1997). Intriguingly, like NAP57, yeast NOP58 interacts with yeast PIH1D1 (Nop17; Gonzales et al. 2005). Therefore, pontin and reptin action may generally require highly charged and unstructured amino acid tails. However, stable interaction with the tails is not part of the process because pontin and reptin bind to NAP57 in the absence of its tail (Fig. 5D). Interestingly, the charged tail of yeast NAP57, Cbf5p, is essential for cell viability (Jiang et al. 1993) and that of yeast NOP56 and NOP58 is important for nucleolar integrity (Colau et al. 2004). In summary, our model seems to apply to general snoRNP biogenesis.

As the name suggests, AAA+ ATPases normally hydrolyze ATP to exert their activities. However, the release activity in the S100 extracts is apparently ATP-independent (Fig. 3C,D). Nevertheless, we cannot rule out that in the extracts ATP (or ADP) has remained tightly bound to pontin and reptin and that a single round of hydrolysis (or release) is sufficient for the observed separation of SHQ1 and NAP57. Also, ATP hydrolysis may only be required for release of the ATPases from NAP57 after SHQ1 has been removed. Regardless, it is conceivable that in the case of the NAP57-SHQ1 complex, pontin and reptin function in an ATP-independent fashion. Thus, despite the ability to coax recombinant pontin and reptin to hydrolyze ATP in vitro, the results are inconsistent (Puri et al. 2007; Gribun et al. 2008; Torreira et al. 2008; McKeegan et al. 2009) and have been questioned (Jha and Dutta 2009). Furthermore, pontin and reptin belong to an evolutionary group of AAA+ ATPases that is separate from the bacterial RuvB helicases (which truly require ATP for unwinding; Iyer et al. 2004; Ammelburg et al. 2006). Therefore, it is possible that simple, perhaps competitive binding is sufficient to separate NAP57 and SHQ1. For example, R2TP binding could reverse the allosteric changes induced in NAP57 by interaction with the SSD, thereby sufficiently loosening the hold of SHQ1 for H/ACA RNA access.

Where in the cell do the tight NAP57-SHQ1 association and the R2TP-mediated separation occur? Without the context of an RNP, NAP57 is unstable and requires chaperones for stabilization (Grozdanov et al. 2009b). Therefore, to prevent aggregation and degradation of NAP57 and binding of random RNAs (Walbott et al. 2011), it is likely that SHQ1 associates with NAP57 at the site of translation in the cytoplasm, or post-translationally. The dimer may then travel into the nucleus by virtue of the multiple nuclear localization signals of NAP57 (Meier and Blobel 1994; Heiss et al. 1999; Youssoufian et al. 1999). Only at the site of transcription of H/ACA RNAs is there a need for SHQ1 to be replaced by the specific RNAs. It is tempting to speculate that the presence of pontin and reptin in transcription and chromatin remodeling complexes (Jha and Dutta 2009; Boulon et al. 2010) puts the machinery for this exchange at the right place at the right time.

Finally, what are the advantages of the tight binding of SHQ1 to NAP57? It assures safe passage of NAP57 through the cell from the point of translation across the nuclear envelope to the site of H/ACA RNA transcription. Similarly, it prevents noncognate RNAs from associating with the RNA binding domain of NAP57 (Li et al. 2011; Walbott et al. 2011). Importantly, it provides a means of regulation of NAP57 availability, e.g., through spatiotemporal control of the activity of pontin and reptin, such as the sumoylation of reptin (Kim et al. 2006). In a more general consideration, the function of pontin and reptin in NAP57•SHQ1 separation may serve as a paradigm for the remodeling of the many other macromolecular complexes these AAA+ ATPases are associated with.

\section{MATERIALS AND METHODS}

\section{DNA and RNA constructs}

All constructs were based on human proteins, except pontin and reptin, which were based on mouse sequences that, however, differ from those in humans by only two conservative changes. Most constructs have been described previously, MBP-NAP57 (pPG17), SHQ1 (pPG18), SHQ1-CS (pPG14), SSD (pPG15), and MBPMCP in Grozdanov et al. (2009b), MBP-NAP $\Delta$ cat (pPG32), MBP-NAP57-cat (pPG48), MBP-NAP57-C (pPG33), MBPNAP57 M350I (pPG61), and MBP-NAP57 M350T (pPG60) in Grozdanov et al. (2009a), pontin (pTIP49) and reptin (pTIP48) in Newman et al. (2000), GST-pontin (pTIP49GST) and GST-reptin (pTIP48GST) in McKeegan et al. (2009). The pontin and reptin constructs were kind gifts from Nick Watkins and Kenny McKeegan (University of Newcastle upon Tyne, UK). MBP-NAP 1-422 (pRM67) and MBP-NAP 31-514 (pRM68) were generated like MBP-NAP 31-422 (pTM193) (Walbott et al. 2011). MBP-SHQ1 (pRM9) and MBP-CS (pRM10) were generated by amplification of 
full-length SHQ1 and its first 90 amino acids, respectively, and cloning into the same vector used to construct MBP-NAP57 (pPG17). Yeast SHQ1 constructs, ySHQ1 (Shq1p), and yCS (CS domain of Shq1p, amino acids 1-144) were cloned as fusions with myc epitopes into pESC-LEU (Agilent Technologies). The ySSD (SSD of Shq1p, amino acids 145-507) with a FLAG epitope was cloned under the control of the GAL10 promoter into pESC-LEU, alone or together with yCS. Complementation analysis was performed exactly as described (Walbott et al. 2011). Human cDNAs for PIH1D1 and RPAP3 were purchased from OriGene Technologies and American Type Culture Collection, respectively, and fused to N- and C-terminal hexa-histidine tags as described for the SHQ1 constructs (Grozdanov et al. 2009b) to generate the bacterial expression vectors for PIH1D1 (pRM18) and RPAP3 (pRM23).

RNA oligonucleotides for siRNA-mediated silencing were described previously, siNAP57 and sifibrillarin (Darzacq et al. 2006), siSHQ1 (Grozdanov et al. 2009b), and sipontin (TIP49) and sireptin (TIP48) (TIP48; Watkins et al. 2004).

\section{Recombinant proteins and pull-down assay}

Recombinant proteins were produced and purified as described (Grozdanov et al. 2009b). All constructs were expressed in the bacterial strain BL21, except for all MBP-NAP57 fusion constructs, which were expressed in Rosetta 2 (Novagen).

Pull-down assays were performed as described (Walbott et al. 2011) with the following experiment-specific alterations. For removal of potential contaminating bacterial RNAs, recombinant proteins $(\sim 5 \mu \mathrm{g})$ were pretreated with RNase A (1000 units). Incubations at the indicated salt concentrations were carried out in the presence of $1 \%$ Triton X-100 for $30 \mathrm{~min}$ at room temperature before or after binding. For release experiments, the MBP-NAP57 and SHQ1 constructs $(\sim 5 \mu \mathrm{g}$ each) were allowed to associate for $25 \mathrm{~min}$ at room temperature before an equal incubation with $10 \mu \mathrm{L} \mathrm{S} 100$ extract $(13 \mu \mathrm{g} / \mu \mathrm{L})$ in $200 \mu \mathrm{L}$ total volume and binding to $25 \mu \mathrm{L}$ amylose resin. HeLa cytosolic S100 extract was prepared as described (Dignam et al. 1983) and kindly provided by Charles Query (Department of Cell Biology, Albert Einstein College of Medicine, Bronx, NY). After adsorption, the beads were washed four times with $1 \mathrm{~mL}$ binding buffer and the proteins eluted into SDS sample buffer. In case of glutathione-Stransferase fusion proteins, glutathione sepharose $4 \mathrm{~B}$ beads were used (GE Healthcare Bio-Sciences). Where indicated, the following chemicals (final concentrations in parentheses) were added with S100, ATP (1 mM), apyrase (10 mg/mL, 1400 units $/ \mathrm{mg}$ ), and geldanamycin (GA, 4 and $8 \mu \mathrm{M})$, all purchased from Sigma. For antibody inhibition studies, $10 \mu \mathrm{L}$ S100 was preincubated overnight at $4^{\circ} \mathrm{C}$ with $3 \mu \mathrm{L}$ antiserum or, in the case of RPAP3 antibodies, with $15 \mu \mathrm{L}$ ascites fluid. To relieve inhibition, antibodies were neutralized (prior to addition to S100) with $5 \mu \mathrm{L}$ of recombinant proteins $(0.5 \mu \mathrm{g} / \mu \mathrm{L})$ for $60 \mathrm{~min}$ at $4^{\circ} \mathrm{C}$. To study concentration dependence, additionally $1 \mu \mathrm{L}$ and $3 \mu \mathrm{L}$ of recombinant proteins were used. All experiments were repeated at least twice (most more frequently) with identical results.

Rabbit antisera (sources in parentheses) against the following antigens were used: pontin, reptin, and PIH1D1 (ProteinTech Group, Inc.); NAP57 (RU8) and NAF1 (CRX6; Darzacq et al. 2006); and SHQ1 (BA10; Grozdanov et al. 2009b). RPAP3 (hSpagh) mouse monoclonal antibodies were a kind gift from Edouard Bertrand (Institut de Génétique Moléculaire de Montpellier,
Montpellier, France) and Solange Moréra (Laboratoire d'Enzymologie et Biochimie Structurales, Gif-sur-Yvette, France).

\section{Western and Northern blotting}

For knockdown experiments, siRNAs were transfected into U2OS cells using Lipofectamine 2000 (Invitrogen) and the cells collected for analysis $48 \mathrm{~h}$ post-transfection as described for Western and Northern blotting (Grozdanov et al. 2009b). For Western blots, mouse monoclonal anti-tubulin (Sigma; $0.3 \mu \mathrm{g} / \mathrm{mL}$ ) and antifibrillarin antibodies (D77 at $1 \mu \mathrm{g} / \mathrm{mL}$; Aris and Blobel 1988), and rabbit polyclonal anti-Nopp140 (RS8; Kittur et al. 2007) and antiNHP2 antisera (CG2; Grozdanov et al. 2009b) were used in addition to those employed in the S100 inhibition experiments above. Probes and procedures for Northern blots were identical to those reported previously (Grozdanov et al. 2009b).

\section{ACKNOWLEDGMENTS}

We thank Edouard Bertrand and Solange Moréra for RPAP3 antibodies, Charles Query for S100 extracts, Nick Watkins and Kenny McKeegan for the pontin and reptin (TIP49/48) constructs, and Susan Smith for critical comments on the manuscript. The study was supported by grants from the National Institutes of Health (GM097752 to U.T.M.) and the Association pour la Recherche sur le Cancer (ARC, to N.L.).

Author contributions: D.L. performed the yeast experiment and with N.L. had the idea of complementing the CS domain of SHQ1 in trans to its SSD. R.M.-P. performed all other experiments, and U.T.M. designed the study and wrote the manuscript.

Received June 15, 2012; accepted July 11, 2012.

\section{REFERENCES}

Ammelburg M, Frickey T, Lupas AN. 2006. Classification of AAA+ proteins. J Struct Biol 156: 2-11.

Aris JP, Blobel G. 1988. Identification and characterization of a yeast nucleolar protein that is similar to a rat liver nucleolar protein. J Cell Biol 107: 17-31.

Boulon S, Marmier-Gourrier N, Pradet-Balade B, Wurth L, Verheggen C, Jády BE, Rothé B, Pescia C, Robert M-C, Kiss T, et al. 2008. The Hsp90 chaperone controls the biogenesis of L7Ae RNPs through conserved machinery. J Cell Biol 180: 579-595.

Boulon S, Pradet-Balade B, Verheggen C, Molle D, Boireau S, Georgieva M, Azzag K, Robert M-C, Ahmad Y, Neel H, et al. 2010. HSP90 and its R2TP/Prefoldin-like cochaperone are involved in the cytoplasmic assembly of RNA polymerase II. Mol Cell 39: 912-924.

Cheung KLY, Huen J, Houry WA, Ortega J. 2010. Comparison of the multiple oligomeric structures observed for the Rvb1 and Rvb2 proteins. Biochem Cell Biol 88: 77-88.

Colau GG, Thiry MM, Leduc VV, Bordonné RR, Lafontaine DLJD. 2004. The small nucle(ol)ar RNA cap trimethyltransferase is required for ribosome synthesis and intact nucleolar morphology. Mol Cell Biol 24: 7976-7986.

Darzacq X, Kittur N, Roy S, Shav-Tal Y, Singer RH, Meier UT. 2006. Stepwise RNP assembly at the site of H/ACA RNA transcription in human cells. J Cell Biol 173: 207-218.

Dignam JD, Lebovitz RM, Roeder RG. 1983. Accurate transcription initiation by RNA polymerase II in a soluble extract from isolated mammalian nuclei. Nucleic Acids Res 11: 1475-1489.

Gallant P. 2007. Control of transcription by Pontin and Reptin. Trends Cell Biol 17: 187-192. 
Gautier T, Bergès T, Tollervey D, Hurt E. 1997. Nucleolar KKE/D repeat proteins Nop56p and Nop58p interact with Nop1p and are required for ribosome biogenesis. Mol Cell Biol 17: 7088-7098.

Godin KS, Walbott H, Leulliot N, van Tilbeurgh H, Varani G. 2009. The box H/ACA snoRNP assembly factor Shqlp is a chaperone protein homologous to Hsp90 cochaperones that binds to the Cbf5p enzyme. J Mol Biol 390: 231-244.

Gonzales FA, Zanchin NIT, Luz JS, Oliveira CC. 2005. Characterization of Saccharomyces cerevisiae Nop17p, a novel Nop58p-interacting protein that is involved in Pre-rRNA processing. J Mol Biol 346: $437-455$.

Gorynia S, Bandeiras TM, Pinho FG, McVey CE, Vonrhein C, Round A, Svergun DI, Donner P, Matias PM, Carrondo MA. 2011. Structural and functional insights into a dodecameric molecular machine-the RuvBL1/RuvBL2 complex. J Struct Biol 176: 279291.

Gribun A, Cheung KLY, Huen J, Ortega J, Houry WA. 2008. Yeast Rvb1 and Rvb2 are ATP-dependent DNA helicases that form a heterohexameric complex. J Mol Biol 376: 1320-1333.

Grozdanov PN, Fernández-Fuentes N, Fiser A, Meier UT. 2009a. Pathogenic NAP57 mutations decrease ribonucleoprotein assembly in dyskeratosis congenita. Hum Mol Genet 18: 4546-4551.

Grozdanov PN, Roy S, Kittur N, Meier UT. 2009b. SHQ1 is required prior to NAF1 for assembly of H/ACA small nucleolar and telomerase RNPs. RNA 15: 1188-1197.

Hamma T, Ferré-D'amare AR. 2010. The box H/ACA ribonucleoprotein complex: Interplay of RNA and protein structures in posttranscriptional RNA modification. J Biol Chem 285: 805-809.

Heiss NS, Girod A, Salowsky R, Wiemann S, Pepperkok R, Poustka A. 1999. Dyskerin localizes to the nucleolus and its mislocalization is unlikely to play a role in the pathogenesis of dyskeratosis congenita. Hum Mol Genet 8: 2515-2524.

Horejsí Z, Takai H, Adelman CA, Collis SJ, Flynn H, Maslen S, Skehel JM, de Lange T, Boulton SJ. 2010. CK2 phospho-dependent binding of R2TP complex to TEL2 is essential for mTOR and SMG1 stability. Mol Cell 39: 839-850.

Huber O, Ménard L, Haurie V, Nicou A, Taras D, Rosenbaum J. 2008. Pontin and reptin, two related ATPases with multiple roles in cancer. Cancer Res 68: 6873-6876.

Huen J, Kakihara Y, Ugwu F, Cheung KLY, Ortega J, Houry WA. 2010. Rvb1-Rvb2: Essential ATP-dependent helicases for critical complexes. Biochem Cell Biol 88: 29-40.

Iyer LM, Leipe DD, Koonin EV, Aravind L. 2004. Evolutionary history and higher order classification of AAA+ ATPases. J Struct Biol 146: 11-31.

Jha S, Dutta A. 2009. RVB1/RVB2: Running rings around molecular biology. Mol Cell 34: 521-533.

Jiang W, Middleton K, Yoon HJ, Fouquet C, Carbon J. 1993. An essential yeast protein, CBF5p, binds in vitro to centromeres and microtubules. Mol Cell Biol 13: 4884-4893.

Jónsson ZO, Jha S, Wohlschlegel JA, Dutta A. 2004. Rvb1p/Rvb2p recruit Arp5p and assemble a functional Ino80 chromatin remodeling complex. Mol Cell 16: 465-477.

Kakihara Y, Houry WA. 2012. The R2TP complex: Discovery and functions. Biochim Biophys Acta 1823: 101-107.

Kanemaki M, Makino Y, Yoshida T, Kishimoto T, Koga A, Yamamoto K, Yamamoto M, Moncollin V, Egly JM, Muramatsu M, et al. 1997. Molecular cloning of a rat $49-\mathrm{kDa}$ TBP-interacting protein (TIP49) that is highly homologous to the bacterial RuvB. Biochem Biophys Res Commun 235: 64-68.

Kim JH, Choi HJ, Kim B, Kim MH, Lee JM, Kim IS, Lee MH, Choi SJ, Kim KI, Kim S-I, et al. 2006. Roles of sumoylation of a reptin chromatin-remodelling complex in cancer metastasis. Nat Cell Biol 8: 631-639.

King TH, Decatur WA, Bertrand E, Maxwell ES, Fournier MJ. 2001. A well-connected and conserved nucleoplasmic helicase is required for production of box C/D and H/ACA snoRNAs and localization of snoRNP proteins. Mol Cell Biol 21: 7731-7746.

Kiss T, Fayet-Lebaron E, Jády BE. 2010. Box H/ACA small ribonucleoproteins. Mol Cell 37: 597-606.
Kittur N, Zapantis G, Aubuchon M, Santoro N, Bazett-Jones DP, Meier UT. 2007. The nucleolar channel system of human endometrium is related to endoplasmic reticulum and R-rings. Mol Biol Cell 18: 2296-2304.

Li H. 2008. Unveiling substrate RNA binding to H/ACA RNPs: One side fits all. Curr Opin Struct Biol 18: 78-85.

Li S, Duan J, Li D, Ma S, Ye K. 2011. Structure of the Shq1-Cbf5Nop10-Garl complex and implications for H/ACA RNP biogenesis and dyskeratosis congenita. EMBO J 30: 5010-5020.

Maillard RA, Chistol G, Sen M, Righini M, Tan J, Kaiser CM, Hodges C, Martin A, Bustamante C. 2011. ClpX(P) generates mechanical force to unfold and translocate its protein substrates. Cell 145: 459-469.

Mason PJ, Bessler M. 2011. The genetics of dyskeratosis congenita. Cancer Genet 204: 635-645.

Matera AG, Terns RM, Terns MP. 2007. Non-coding RNAs: Lessons from the small nuclear and small nucleolar RNAs. Nat Rev Mol Cell Biol 8: 209-220.

Matias PM, Gorynia S, Donner P, Carrondo MA. 2006. Crystal structure of the human AAA+ protein RuvBL1. J Biol Chem 281: 38918-38929.

McKeegan KS, Debieux CM, Boulon S, Bertrand E, Watkins NJ. 2007. A dynamic scaffold of pre-snoRNP factors facilitates human box C/D snoRNP assembly. Mol Cell Biol 27: 6782-6793.

McKeegan KS, Debieux CM, Watkins NJ. 2009. Evidence that the AAA+ proteins TIP48 and TIP49 bridge interactions between $15.5 \mathrm{~K}$ and the related NOP56 and NOP58 proteins during box C/D snoRNP biogenesis. Mol Cell Biol 29: 4971-4981.

Meier UT. 2005. The many facets of H/ACA ribonucleoproteins. Chromosoma 114: 1-14.

Meier UT. 2006. How a single protein complex accommodates many different H/ACA RNAs. Trends Biochem Sci 31: 311-315.

Meier UT, Blobel G. 1994. NAP57, a mammalian nucleolar protein with a putative homolog in yeast and bacteria. J Cell Biol 127: 1505-1514.

Mueller-Cajar O, Stotz M, Wendler P, Hartl FU, Bracher A, HayerHartl M. 2011. Structure and function of the AAA+ protein CbbX, a red-type Rubisco activase. Nature 479: 194-199.

Newman DR, Kuhn JF, Shanab GM, Maxwell ES. 2000. Box C/D snoRNA-associated proteins: Two pairs of evolutionarily ancient proteins and possible links to replication and transcription. RNA 6: $861-879$.

Ogura T, Wilkinson AJ. 2001. AAA+ superfamily ATPases: Common structure-diverse function. Genes Cells 6: 575-597.

Puri T, Wendler P, Sigala B, Saibil H, Tsaneva IR. 2007. Dodecameric structure and ATPase activity of the human TIP48/TIP49 complex. J Mol Biol 366: 179-192.

Singh M, Gonzales FA, Cascio D, Heckmann N, Chanfreau G, Feigon J. 2009. Structure and functional studies of the CS domain of the essential H/ACA ribonucleoparticle assembly protein SHQ1. J Biol Chem 284: 1906-1916.

Stebbins CE, Russo AA, Schneider C, Rosen N, Hartl FU, Pavletich NP. 1997. Crystal structure of an Hsp90-geldanamycin complex: Targeting of a protein chaperone by an antitumor agent. Cell 89: 239-250

Torreira E, Jha S, López-Blanco JR, Arias-Palomo E, Chacón P, Cañas C, Ayora S, Dutta A, Llorca O. 2008. Architecture of the pontin/ reptin complex, essential in the assembly of several macromolecular complexes. Structure 16: 1511-1520.

Venteicher AS, Meng Z, Mason PJ, Veenstra TD, Artandi SE. 2008. Identification of ATPases pontin and reptin as telomerase components essential for holoenzyme assembly. Cell 132: 945-957.

Walbott H, Machado-Pinilla R, Liger D, Blaud M, Rety S, Grozdanov PN, Godin K, van Tilbeurgh H, Varani G, Meier UT, et al. 2011. The H/ACA RNP assembly factor SHQ1 functions as an RNA mimic. Genes Dev 25: 2398-2408.

Wang C, Meier UT. 2004. Architecture and assembly of mammalian $\mathrm{H} / \mathrm{ACA}$ small nucleolar and telomerase ribonucleoproteins. EMBO J 23: $1857-1867$ 
Watkins NJ, Dickmanns A, Lührmann R. 2002. Conserved stem II of the box C/D motif is essential for nucleolar localization and is required, along with the $15.5 \mathrm{~K}$ protein, for the hierarchical assembly of the box C/D snoRNP. Mol Cell Biol 22: 83428352.

Watkins NJ, Lemm I, Ingelfinger D, Schneider C, Hossbach M, Urlaub H, Lührmann R. 2004. Assembly and maturation of the U3 snoRNP in the nucleoplasm in a large dynamic multiprotein complex. Mol Cell 16: 789-798.

Yang PK, Rotondo G, Porras T, Legrain P, Chanfreau G. 2002. The Shq1p•Naf1p complex is required for box H/ACA small nucleolar ribonucleoprotein particle biogenesis. J Biol Chem 277: $45235-45242$.
Ye K. 2007. H/ACA guide RNAs, proteins and complexes. Curr Opin Struct Biol 17: 287-292.

Youssoufian H, Gharibyan V, Qatanani M. 1999. Analysis of epitopetagged forms of the dyskeratosis congenital protein (dyskerin): Identification of a nuclear localization signal. Blood Cells Mol Dis 25: 305-309.

Zhao R, Kakihara Y, Gribun A, Huen J, Yang G, Khanna M, Costanzo M, Brost RL, Boone C, Hughes TR, et al. 2008. Molecular chaperone Hsp90 stabilizes Pih1/Nop17 to maintain R2TP complex activity that regulates snoRNA accumulation. J Cell Biol 180: 563-578.

Zhao C, Smith EC, Whiteheart SW. 2012. Requirements for the catalytic cycle of the N-ethylmaleimide-Sensitive Factor (NSF). Biochim Biophys Acta 1823: 159-171. 

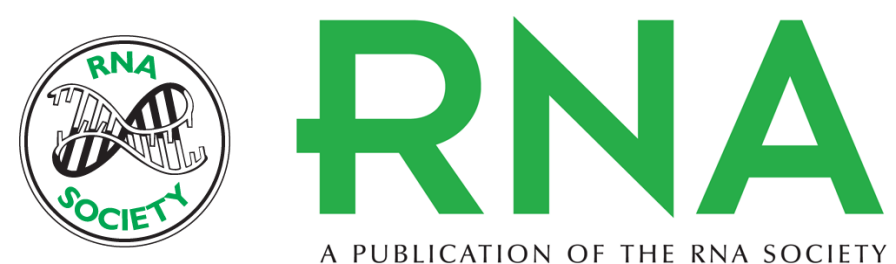

A PUBLICATION OF THE RNA SOCIETY

\section{Mechanism of the AAA+ ATPases pontin and reptin in the biogenesis of H/ACA RNPs}

Rosario Machado-Pinilla, Dominique Liger, Nicolas Leulliot, et al.

RNA 2012 18: 1833-1845 originally published online August 24, 2012

Access the most recent version at doi:10.1261/rna.034942.112

\section{References This article cites 59 articles, 22 of which can be accessed free at: http://rnajournal.cshlp.org/content/18/10/1833.full.html\#ref-list-1}

License Email Alerting $\begin{aligned} & \text { Receive free email alerts when new articles cite this article - sign up in the box at the } \\ & \text { Service }\end{aligned}$ top right corner of the article or click here. 